\title{
VÄRLDEN SOM VERKLIGHET, FÖRESTÄLLNING OCH VIRTUALITET
}

Människors föreställningar om världen utom synhåll i tid och rum frambesvärjs av de medier för kommunikation som står till förfogande vid olika tider, på olika platser, i olika samhällen. Språkögat, som aktiverar minne och fantasi, sätts i rörelse i det språkliga umgänget människor emellan och skapar de inre föreställningsvärldar som sedan människoblivandets tid varit grunden för vår kulturella kompetens. Den verbala kraften laddades i berättelse och sång, fick ännu starkare påminnelsekraft när den frigjordes från talet och fästes i skrift, mångfaldigades i den tryckta bok- och tidningsvärlden. Dock - muntligheten fick en häpnadsväckande revansch med radiovågornas hjälp.

Men också visuella medier har från tidens begynnelse hjälpt till med att frammana en föreställd värld - bilden, mimen, dansen. Mim och gest sätts samman med ord till teater, bild med utsaga till ikonografi och läromedel. När sedan detta 'verbovisuella' språk kombinerats med ljud och rörlig bild har det blivit ett instrument, ständigt förfinat, för produktionen av alltmer suggestiva och sofistikerade drömbilder, förledande bekväma att flytta in i våra föreställningsvärldar.

Förhållandet mellan den reella och föreställda världen förskjuts på ett oförutsebart sätt i datoråldern. Arno V. Nielsen visar hur lineariteten i det språkliga berättandet plötsligt bryts i ett medium som närmar sig den föreställda världens associativa dynamik. Den tröga rörelsen i rummet och i skriftspråkets bundna läsriktning bryts i ett virtuellt rum utan avstånd vare sig i tid eller rum. Snabbt som tanken(!) rör vi oss fingerfärdigt mellan alla tiders texter och platser; associationernas flöde materialiseras på våra bildskärmar - tankefriheten har fått ett oöverträffat datorstöd.

I själva verket medger virtualiteten inte bara simuleringar utan nybyggda 'verkligheter', där du företräds av en självskapad önskepersona, din avatar, i den bästa av drömda världar. Informationssamhällets virtuella värld är på god väg att ersätta den verkliga! 
NORDISK MUSEOLOGI $1997 \cdot 2$

2 Hur ska det historiska minnets medium, museerna, som mödosamt fogar samman fragment av den reella världen till sina versioner av tänkta världar, förhålla sig till de datorproducerade virtuella världarna? Museernas tövande entré på den digitala scenen har många aspekter. Jon Birger Østby beskriver ett grundläggande problem: att skapa samverkan för ett gemensamt digitalt museispråk. Eija Liukkonen och MikaVäyrynen har etablerat Statens Museum för Konst i Helsingfors på

Internet och berättar om erfarenheterna av detta redan avancerade projekt.

I juni i år anordnade danska Museumshøjskolen ett museologiskt seminarium i Vester Vedsted för att påminna om den första av de danska museipedagogiska sommarkurserna. Själva museologi-begreppet belystes i tre föreläsningar som återges här. David Anderson, som på regeringsuppdrag hade utarbetat den i våras publicerade 'A Common Wealth: Museums and Learning in the UK' (rapporten anmäls för övrigt i numret av Inge Meldgaard), diskuterar en ny möjlig museologidefinition. Ivo Maroeviç ger museologin en plats bland informationsvetenskaperna och Friedrich Waidacher argumenterar för museologins filosofiska grund i ett mänskligt existentiellt behov av historisk identitet.

Till utställningsspråkens problematik återvänder slutligen Lene Otto och Lykke Pedersen i sin uppsats om ett utställningsprojekt knutet till danska Nationalmuseet. De tar sin utgångspunkt i skillnaden mellan presenterande och tolkande utställningar och diskuterar möjliga kombinationer.

Per-Uno Agren

\footnotetext{
Apropå

att den svenska utredningen om IT i kulturens tjänst hävdar att tillgången till kulturnätet skall vara en (kostnads)fri demokratisk rättighet för alla, finns anledning påminna om att en (kostnads) fri tillgång till det gemensamma kulturarvet i museerna borde vara lika självklar.

En ojämn kamp utkämpas i London om den fortfarande kostnadsfria entrén till British Museum och National Gallery: Att tvinga människor att betala för att få besöka våra stora offentliga museer innebär ett upprörande förräderi gentemot de upplysningsidéer som skapade dem, skriver The Sunday Times (26/11/96). Och fortsätter: Att tillåta att även detta kulturområde kommersialiseras, innebär en degradering av våra kulturella värden. I grunden handlar det om tillgången till en erfarenhet - upplevelsen av ett gemensamt kulturarv - som vi, som nation, en gång betraktade som alltför värdefull för att kunna kostnadsbelägga.
} 